\title{
PROCUREMENT OF ORGANIC FOOD BY LATVIAN SCHOOLS
}

\author{
Lasma Aleksejeva ${ }^{1}$, Mg.oec., Modrite Pelse ${ }^{2}$, Dr.oec. \\ ${ }_{1,2}^{2}$ Faculty of Economics and Social Development, Latvia University of Life Sciences and Technologies
}

\begin{abstract}
Organic and local food are a focus in discussions on sustainable school catering systems. A number of European regions have already implemented public procurement policies that give a priority to the use of organic food in school meals. At present, Latvia has not designed a single policy on public food procurement. As a result, progression towards green public procurement is hindered. The research aim is to analyse the public procurement of organic food by educational institutions in Latvia. The research employed document analysis, the monographic method and descriptive statistics. A case study of the involvement of certified organic enterprises focused on the results of the EU-co-funded programme "School Milk and Fruit" for the period 2014-2017. The research found that local farmers could provide local schools and kindergartens with organic food, as the organic farming system was economically diversified. Besides, farmers preferred selling their organic produce in the market rather than using it for self-consumption. The current involvement of certified organic enterprises in public food procurement is low. It is affected by both exogenous and endogenous factors. Strategies on public organic food procurement should be designed by local governments based on an analysis of the situation in the particular region. The analysis would allow identifying territorial factors and market constraints, based on which the local governments could design an organic food "basket", determining the price and product quality standards.
\end{abstract}

Keywords: organic food, public procurement, supply chain, schools.

JEL code: Q1; O13; P36.

\section{Introduction}

The European Union moves towards environment-friendly public procurement by educational institutions. Organic and local food is in the centre of discussion on sustainable school catering systems. It is believed the public organic food procurement contributes to the regional economy and sustainable resource use. Over the last decades, researchers as well as national and municipal institutions have focused on sustainable food, including organic, procurement by schools (Filippini R., De Nonib I. et al., 2018). At present, a number of European regions have already implemented public procurement policies that give a priority to the use of organic food in school meals (Braun $\mathrm{L}$. C., Rombach M et al., 2018). For example, in the city of Malmo in Sweden, organic food procured by schools account for $40 \%$ of the total amount of food procured by schools; in Rome (Italy) $69 \%$, while in Denmark from 2015 onwards organic food has to make up $90 \%$ of the total amount of food procured (Biologisko partikas produktu...,2014). At present, Latvia does not have a single policy on public food procurement by educational institutions. Public procurement is carried out in accordance with the Public Procurement Law and Cabinet Regulation No. 172 Regulations regarding Nutritional Norms for Educatees of Educational Institutions, Clients of Social Care and Social Rehabilitation Institutions and Patients of Medical Treatment Institutions. The economically most advantageous tender for the supply of food to educational institutions is determined based on a criteria rating scale. A good illustrative example regarding organic food consumption at educational institutions in Latvia is the EU-co-funded Rural Support Service programme for the supply of vegetables, fruits and milk to schools. To date, the key barriers to the supply of organic food to schools and kindergartens in Latvia were considered to be high prices and bureaucratic rules for public procurement. Approximately $20 \%$ of the total amount of food consumed by the population is the food procured by national and municipal institutions, and a considerable proportion of it is consumed by schools and kindergartens (Biologisko partikas produktu..., 2014). The research object is organic food. The research subject is the demand of organic food in the 
public procurements by educational institutions in Latvia. The research aim is to analyse the public procurement of organic food by educational institutions in Latvia. Research tasks:

1) to analyse the organic food production output in the years 2012 to 2017;

2) to estimate the consumption trends of fruits, vegetables, fresh milk within the EU co-funded programmes for public schools from 2014 till 2017;

3 ) to define the main obstacles for inclusion of organic food within the public procurements for schools in Latvia.

The research analysed the quantity of organic food produced in the period 2012-2017 by food category as well as the consumption of the organic food. Employing the case study method, the research analysed previous school food programmes regarding the supply of fruits, vegetables and fresh milk implemented in the period 2014-2017 as well as identified the key obstacles to the public procurement of organic food by schools.

\section{Research results and discussion}

\section{Output of organic food in Latvia in the period 2012-2017}

The most popular kinds of organic food in the EU were fresh fruits and vegetables, accounting for approximately a fifth of the total organic food turnover in Italy, Ireland, Norway, Sweden and Denmark. The Nordic countries demonstrated a very high proportion of organic dairy products in total milk output, while organic meat products were very popular in Belgium, the Netherlands, Finland and France, which comprised about $10 \%$ of the total quantity of organic food. Organic drinks had a considerable market share in Croatia and France, wine in particular, accounting for more than $10 \%$ of the total market (Organic farming statistics..., 2015).

The organic farming system in Latvia is economically diversified. The dominant organic industries were crop production (36\%), milk (21\%), beef cattle (9\%), pig (9\%), fruit (8\%), vegetable (8\%) and goat production $(8 \%)$, while sheep, rabbit and poultry production are less popular (Biologiska lauksaimnieciba..., 2013). In the period 2012-2017, the highest growth rate was reported for vegetable production $(58.3 \%)$ and hen egg production $(31.4 \%)$, while the production of meat ($11.1 \%)$, potato $(-3.9 \%)$ and honey $(-1.4 \%)$ decreased (Table 1$)$.

Table 1

Output of certified organic food in Latvia in the period 2012-2017, thou. $t$

\begin{tabular}{|c|c|c|c|c|c|c|c|}
\hline Product & 2012 & 2013 & 2014 & 2015 & 2016 & 2017 & $\begin{array}{c}\text { Average } \\
\text { change, \% }\end{array}$ \\
\hline Milk, thou.t & 69.1 & 69.6 & 74.9 & 83.5 & 98 & 96.5 & 7.1 \\
\hline Grain, thou.t & 56.9 & 50.9 & 57.8 & 77.8 & 85.5 & 80.9 & 8.4 \\
\hline Potato, thou.t & 21.7 & 19.2 & 18.1 & 19.5 & 19.6 & 17.5 & -3.9 \\
\hline Meat, thou.t & 3.2 & 3.5 & 2.9 & 2.7 & 1.6 & 1.6 & -11.1 \\
\hline Fruits and berries, thou.t & 1.5 & 1.9 & 2.6 & 2 & 3.2 & 2.5 & 15.7 \\
\hline Vegetables, thou.t & 0.8 & 3.2 & 2.4 & 2.2 & 2.9 & 2.7 & 58.3 \\
\hline Hen eggs (mln. pcs.) & 0.55 & 0.55 & 0.63 & 1.2 & 1.6 & 1.9 & 31.4 \\
\hline Honey, thou.t & 0.25 & 0.23 & 0.26 & 0.5 & 0.5 & 0.4 & -1.4 \\
\hline
\end{tabular}

Source: authors' calculations based on Latvijas lauksaimnieciba 2015, 2016, 2017

In 2017, the proportions of grain ( 80.9 thou.t.) and potato (17.5 thou.t) in the total output of crops were the highest, while milk production (96.5 thou.t.) had the highest proportion in the total output of livestock products. An analysis of ten educational institution statutes in relation to food purchase through public procurement tendering revealed that the food was divided into 14 categories: 1) milk and dairy products; 2) meat and meat products; 3) frozen products; 4) bread 
and bakery products; 5) non-perishable foods; 6) eggs; 7) sugar; 8) fruits and vegetables; 9) apples; 10) blackcurrants; 11) potato; 12) cabbage; 13) carrot; and 14) red beet. This allows concluding that out of the 14 categories, sugar and part of non-perishable foods, e.g. rice, salt and cacao, are not organic products. Any educational institution procures food in accordance with the Public Procurement Law; therefore, the procurement procedures and documentation are the same. The tendering process is usually carried out in summer. This, in its turn, makes planning operations and supplying the products difficult for businesses. Besides, procurement documents prescribe one winner in each product category, which, in its turn, prevents organic farms from supplying, for example, buckwheat in case the farms cannot supply another kind of non-perishable foods. In this way, educational institutions give advantages to wholesalers rather than local farmers.

According to a fact sheet website on the European Union, a large number of self-consumption farms is characteristic of Latvia (Faktu lapa par..., 2015). Basic data on organic food are shown in Table 2. The authors identified the situation with organic farming based on a case study.

Table 2

\section{Production, sales and self-consumption of organic food in Latvia in the period} 2012-2017, thou. $t$

\begin{tabular}{|c|c|c|c|c|c|c|c|}
\hline \multirow{2}{*}{$\begin{array}{l}\text { Primary } \\
\text { products }\end{array}$} & \multicolumn{3}{|c|}{2012} & \multicolumn{3}{|c|}{2017} & \multirow{2}{*}{$\begin{array}{c}\text { Change in } \\
\text { quantity } \\
\text { sold } \\
2017 / 2012 \\
\end{array}$} \\
\hline & Produced & Sold & $\begin{array}{c}\text { Self- } \\
\text { consumed }\end{array}$ & Produced & Sold & Self-consumed & \\
\hline Milk & 69.1 & 56.66 & 12.44 & 96.5 & 79.23 & 17.27 & 22.56 \\
\hline Grain & 56.9 & 19.35 & 37.55 & 80.9 & 36.97 & 43.93 & 17.63 \\
\hline Potato & 21.7 & 4.56 & 17.14 & 17.5 & 6.20 & 11.31 & 1.64 \\
\hline Meat & 3.2 & 2.94 & 0.26 & 1.6 & 1.40 & 0.20 & -1.54 \\
\hline $\begin{array}{l}\text { Fruits and } \\
\text { berries }\end{array}$ & 1.5 & 0.77 & 0.74 & 2.5 & 1.04 & 1.46 & 0.27 \\
\hline Vegetables & 0.8 & 0.18 & 0.62 & 2.7 & 0.93 & 1.77 & 0.75 \\
\hline Hen eggs & 0.55 & 0.26 & 0.29 & 1.9 & 0.79 & 1.11 & 0.54 \\
\hline Honey & 0.25 & 0.16 & 0.09 & 0.4 & 0.21 & 0.19 & 0.05 \\
\hline
\end{tabular}

Source: authors' calculations based on Latvijas lauksaimnieciba, 2013, 2018

In 2012, as shown in Table 2, the most market-oriented commodities were milk, meat and honey. The proportion of quantity sold for the mentioned commodities exceeded $70 \%$, whereas the other commodities - grain, potato, fruits, berries, vegetables and hen eggs - were mainly self-consumed. In 2017 compared with 2012, the kinds of market-oriented commodities have not changed, yet overall the quantity sold increased for all the product categories, except meat. This means organic farmers perceive this kind of farming as a source of profits and consider sales opportunities, environmental protection and healthy nutrition.

Overall, one can conclude that educational institutions can potentially purchase organic food. An illustrative example regarding organic food consumption at educational institutions in Latvia is the EU-co-funded Rural Support Service programme for the supply of vegetables, fruits and milk to schools.

\section{Organic food for the EU-co-funded programme "School Milk and Fruit"}

The EU-co-funded programme "Support for Purchasing Dairy Products for Educatees" or the "School Milk" programme is one of the single market support instruments, even though the key objectives of the programme pertain to promoting healthy nutrition and milk consumption among schoolchildren rather than market regulation. On 1 October 2015, the principles of calculation of national co-funding rates were changed, pegging the rates to the quarterly change in milk purchase 
prices (Table 3). Furthermore, the national co-funding rates were differentiated according pack volume (packs sized less than $250 \mathrm{ml}$ and packs sized more than $250 \mathrm{ml}$ ), including the possibility to set an extra subsidy for milk produced in compliance with organic farming scheme requirements. At the same time, maximum support thresholds (comprised of EU funding and national co-funding) and maximum costs pertaining to milk processing, packaging, transport and distribution applicable to every academic year were set as well. In Latvia, any milk producer, dairy product distributor, the educational institution itself as well as the local government in whose administrative territory the particular educational institution is located may participate in the programme. The programme is administered by the Rural Support Service. National co-funding is granted for the supply of pasteurised drinking milk (without additives, flavourings, sweeteners etc.) to preschool and general education $1^{\text {st }} 9^{\text {th }}$-year educatees. The educatees are given an opportunity to get a glass of milk (up to $250 \mathrm{ml}$ ) free of charge every day owing to the national co-funding. In the reporting period from the academic year 2014/2015 through to the academic year 2016/2017, the implementation of the programme "School Milk" continued expanding in terms of amount of support paid and number of educatees involved. For example, the amount of support paid (EU funding and national co-funding put together) in the reporting period rose by $4 \%$ or EUR 111.4 thou., while the number of educatees who received dairy products under the programme increased by $8.2 \%$ or 17.8 thou. (Table 3 ).

Table 3

\section{Implementation of the programme "School Milk" in the academic years} 2014/2015-2016/2017 in Latvia

\begin{tabular}{|c|c|c|c|}
\hline Academic year & $\begin{array}{c}2014 / 2015 \\
(01.09 .2014- \\
31.08 .2015) \\
\end{array}$ & $\begin{array}{c}2015 / 2016 \\
(01.09 .2015- \\
31.08 .2016) \\
\end{array}$ & $\begin{array}{c}2016 / 2017 \\
(01.09 .2016- \\
08.06 .2017) \\
\end{array}$ \\
\hline Number of educational institutions involved & 1037 & 1086 & 1083 \\
\hline Number of educates, thou. & 217.6 & 233.1 & 235.4 \\
\hline Quantity of milk and dairy products, $t$ & 4176.6 & 4761.9 & 4220.3 \\
\hline $\begin{array}{l}\text { Purchase price of non-pasteurised milk, the } \\
\text { average for a 3-year period, EUR/I }\end{array}$ & 0.1869 & 0.1869 & 0.1869 \\
\hline Support per litre of non-pasteurised milk, EUR/I: & $x$ & $x$ & $x$ \\
\hline Organic milk & 0.9137 & 0.8945 & 1.0198 \\
\hline Other milk & 0.8763 & 0.8751 & 0.9824 \\
\hline Bidders involved in the programme & 115 & 115 & 115 \\
\hline Certified organic enterprises & 0 & 0 & 0 \\
\hline Conventional enterprises & 115 & 115 & 115 \\
\hline Support paid (EU and national funding), thou. EUR & 2943.5 & 2853.3 & 3054.9 \\
\hline incl. EU funding, thou. EUR & 758.0 & 864.0 & 765.9 \\
\hline incl. national funding, thou. EUR & 2185.4 & 1989.3 & 2288.9 \\
\hline
\end{tabular}

Source: authors' calculations based on RSS and Ministry of Agriculture report data, 2017

In the period of analysis, as showed in Table 3, not a single certified organic enterprise participated in the School Milk programme, even though the output of organic milk rose by $7.1 \%$ a year in the period 2012-2017. This means schoolchildren could be provided with organic milk, yet it was not done because out of all the procurement eligibility criteria, the priority was given to the lowest price on milk.

However, the European Commission programme "School Fruit" is a way how the Member States, using national and EU funding, can provide schoolchildren with free fruits and vegetables with the aim of increasing the consumption of the products as well as contributing to healthy eating habits among the school children. In the academic year 2016/2017, 780 schools participated in the programme $-0.1 \%$ fewer than in the previous academic year -, yet the number was larger than 
the five-year average (778 schools) (Table 4). Under the programme, schoolchildren received 100 grams of fresh fruits (apples, peaches and large cranberries), vegetables (cabbage, kohlrabi, carrot, swede and pumpkin) or a portion of assorted products free of charge three times a week.

\section{Implementation of the programme "School Fruit" in the academic years} 2014/2015-2016/2017 in Latvia

\begin{tabular}{|c|c|c|c|}
\hline Characteristics & $\begin{array}{c}2014 / 2015 \\
(03.11 .2014- \\
27.02 .2015) \\
\end{array}$ & $\begin{array}{c}2015 / 2016 \\
(02.11 .2015- \\
26.02 .2016) \\
\end{array}$ & $\begin{array}{c}2016 / 2017 \\
(01.11 .2016- \\
17.02 .2017)\end{array}$ \\
\hline $\begin{array}{l}\text { Number of schoolchildren - \% of the total } \\
\text { number of general day-school schoolchildren }\end{array}$ & 92.7 & 94.4 & 97.4 \\
\hline Number of educational institutions involved & 793 & 781 & 785 \\
\hline Quantity of fruits and vegetables distributed, $t$ & 711.7 & 719.0 & 684.8 \\
\hline $\begin{array}{l}\text { Fruit and vegetable subsidy rate, EUR/100 g } \\
\text { (unpacked/paced) }\end{array}$ & $x$ & $x$ & $0.12 / 0.16$ \\
\hline Subsidy if products are organic, EUR/100 g & $x$ & $x$ & 0.03 \\
\hline Bidders involved in the programme & 132 & 122 & 267 \\
\hline incl. certified organic enterprises & $x$ & $x$ & 5 \\
\hline $\begin{array}{l}\text { Support paid (EU and national funding), thou. } \\
\text { EUR }\end{array}$ & 1109.2 & 1114.1 & 1080.0 \\
\hline incl. EU funding, thou. EUR & 850.2 & 774.6 & 827.8 \\
\hline incl. national funding, thou. EUR & 259 & 259.4 & 252.1 \\
\hline
\end{tabular}

Source: authors' calculations based on RSS and Ministry of Agriculture report data, 2017

The Table 4 data allow concluding that the amount of vegetables distributed varied from year to year. Out of all the fruit and vegetable suppliers approved by the Rural Support Service, five were organic enterprises: the farm "Liepkalni-Vezi”, the farm "Kurpnieki”, the agricultural service cooperative "Zalais Grozs”, the farm „Mazie Gavari" and the agricultural service cooperative "Latgales Ekoprodukti”. In general, one can conclude that farmers were reluctant to participate in the school food programmes.

\section{Barriers and potential solutions to the inclusion of organic food in school food programmes}

Organic food procurement is a structured set of activities affected by a number of factors. First, it is the seasonality of and logistics for organic foods (Sonnino, 2009; Risku-Norja and Loes, 2016; Mikkelsen and Sylvest, 2012). For example, the Riga Waldorf School has hired a cook who prepares dishes from seasonal products without using imported vegetables in order to reduce the impact of seasonality on the school menu. As pointed out by the director of the school, "catering enterprises can be flexible enough, yet they are often reluctant to purchase domestic vegetables, as their profits depend on the costs of inputs they buy" (Biologisko partikas produktu..., 2014). At the same time, a study done in Northern Ireland revealed that the introduction of organic food has to be the initiative by catering enterprise management, and the policies of local governments on domestic and certified products have to be also taken into account (Filippini R. , Nonib De I. At al., 2018). In the opinion of the authors, the shorter the food supply chain is, the easier the communication among the parties involved is and the higher the confidence in product quality is. In Latvia, public food procurement requirements usually prescribe that the distance for the delivery of the food has to be less than $100 \mathrm{~km}$. This, in its turn, restricts the delivery of food to cities from remote rural areas. Besides, food with short expiry dates (bread and bakery products, milk and dairy products, meat and meat products) has to be delivered three times a week, while the other foods have to be delivered one-two times a month. In the opinion of the authors, educational institutions have to take into consideration the frequency of food delivery by farmers when producing their public food 
procurement rules. The logistics cost decreases farmer profits. For this reason, optimum, i.e. longer delivery times should be set for the food that could be stored for a long period.

Second, unlike wholesalers that can often meet quality standards and food safety and hygiene requirements, domestic organic food suppliers are unable to meet quality standards (RiskuNorjaandLoes, 2016). For this reason, wholesalers are better suited for public procurement by schools in urban areas, as they can supply the required quantity of food within the desired delivery time and at the required quality.

Third, organic food prices are considered to be one of the most important disadvantages of organic food, as organic food consumption is not viewed from the environmental and economic perspectives. (Mikkelsen and Sylvest, 2012).

Fourth, the inclusion of organic food in public procurement largely depends on the parties involved: national institutions, catering enterprises and local governments (Galli et al., 2014). According to the director of the Riga Waldorf School, "organic food could not be procured without support provided by parents and the understanding of the administration of the school that it is worth investing more time and changing practices in order that the schoolchildren can consume domestic organic food" (Biologisko partikas produktu..., 2014).

Fifth, the inclusion of organic food in school food programmes depends on market constraints, e.g. the availability and cost of organic food compared with those for conventional food (Mikkelsen and Sylvest, 2012; Risku-Norja and Loes, 2016).

Sixth, the structure of organic food procurement might be affected by territorial factors that, on the one hand, indicate the type, diversity and spread of organic farms in the region and, on the other hand, pertain to other territorial aspects, e.g. population density, age structure etc. (Torjusen et al., 2004; Lehtinen, 2012). In the opinion of the authors, procurement documentation has to be prepared in a timely manner - in winter months - so that before sowing, farmers know the quantities of vegetables needed to be supplied next autumn. Unfortunately, practice shows that national and municipal institutions announce calls for tenders in summer when farmers have sown their fields and have already made contracts with potential buyers.

\section{Conclusions, proposals, recommendations}

1) Public organic food procurement could be a significant local economy instrument for promoting sustainable food consumption. In Latvia, farmers could provide local schools and kindergartens with organic food, as the organic farming system is economically diversified. Besides, farmers prefer selling their organic produce in the market rather than using it for self-consumption.

2) At present in Latvia, certified organic enterprises are reluctant to participate in public procurement. In the period 2014-2017, five entrepreneurs participated in the programme "School Milk and Fruit", while not a single entrepreneur offered to supply organic milk to schools and kindergartens. At the same time in Latvia, the output of organic milk and fruits as well as vegetables exceeds the demand for them.

3) The participation of certified organic producers in public food procurement is affected by both exogenous and endogenous factors. Strategies on public organic food procurement should be designed by local governments based on an analysis of the situation in the particular region. The analysis would allow identifying territorial factors and market constraints, based on which the local governments could design an organic food "basket", determining the price and product 
quality standards. Institutions announcing calls for tenders have to take into consideration agricultural seasonality, which affects the production and sales of agricultural products.

\section{Bibliography}

1. Biologiska lauksaimnieciba 2007-2020 (Organic Farming 2007-2020) (2013). Latvian Organic Farmers Association.

Retrieved:http://webcache.googleusercontent.com/search?q=cache:wfCiLkgXv4wJ:laukutikls.Iv/system/files _force/informativie_materiali/lbla_nozares_ekspertu_zinojums_2013.pdf \%3Fdownload \%3D1+\&cd=15\&hl= Iv\&ct=clnk\&gl=Iv. Access:10.01.2019.

2. Biologisko partikas produktu iepirkums skolas - Rigas Valdorfskolas piemers un praktiski padomi (2014). (Organic Food procurement by Schools: the Example and Practical Advice of the Riga Waldorf School). Retrieved: http://www.lbla.Iv/bio-partikas-produktu-iepirkums-skolas\#more-1367. Access: 09.01.2019

3. Braun, L.C., Rombach, M., Häring, M. A., and Vera Bitsch V. (2018). A Local Gap in Sustainable Food Procurement: Organic Vegetables in Berlin's School Meals. Retrieved: https://www.mdpi.com/20711050/10/11/4245/htm. Access:10.01.2019.

4. Faktu lapa par Lauku attistibas programmu Latvijai (Fact sheet on the Rural Development Programme of Latvia) 2014-2020 (2015). European Commission. Retrieved: http://ec.europa.eu/agriculture/ruraldevelopment-2014-2020/country-files/Iv/factsheet_Iv.pdf. Access:10.01.2019.

5. Filippini, R., Noni De, I., Corsi, S., Bocchi, S. (2018). Sustainable School Food Procurement: What factors Do Affect the Introduction and the Increase of Organic Food? Food Policy, Volume 76, April 2018, pp. 109119.

6. Galli, F., Brunori, G., Di Iacovo, F., Innocenti, S., (2014). Co-producing Sustainability: Involving Parents and Civil Society in the Governance of School Meal Services. A case study from Pisa, Italy. Sustainability 6, pp. 1643-1666.

7. Haack, M.; von Münchhausen, S.; Häring, A.M. (2016). Discrepancy between Theory and Practice: Procurement of Local and Organic Food in Public Catering Systems. IFSA Conference Proceedings. Retrieved: https://www.harper-adams.ac.uk/events/ifsa/papers/5/5.9\%20Haack.pdf. Access: 10.12.2018.

8. Kopsavilkums par augli skolai programmu (Summary of the School Fruit Programme) (2017). Retrieved:http://www.lad.gov.lv/files/statistika_augli_skolai_25012017_3f2f1.pdf. Access:04.12.2018

9. Kopsavilkums par skolas piena programmu (Summary of the School Milk Programme) (2017). Rural Support Service. Retrieved:http://www.lad.gov.Iv/files/statistika_skolas_piens_24012017_65291.pdf. Access:04.12.2018.

10. Latvijas lauksaimnieciba (Agriculture of Latvia) (2013). Ministry of Agriculture of the Republic of Latvia. Retrieved: https://www.zm.gov.Iv/public/files/CMS_Static_Page_Doc/00/00/00/29/28/LS_ZINOJUMS_2013.pdf. Access:04.01.2019.

11. Latvijas lauksaimnieciba (Agriculture of Latvia) (2015). Ministry of Agriculture of the Republic of Latvia. Retrieved:https://www.zm.gov.Iv/public/files/CMS_Static_Page_Doc/00/00/00/63/66/LS_gadazinojums_20 15.pdf, Access:04.01.2019.

12. Latvijas lauksaimnieciba (Agriculture of Latvia) (2016). Ministry of Agriculture of the Republic of Latvia. Retrieved: (https://www.zm.gov.Iv/public/files/CMS_Static_Page_Doc/00/00/00/90/30/fs01usersLinda.BirinaDesktopAA2016_lauksaimniecibasgadazinojums.pdf. Access:04.01.2019.

13. Latvijas lauksaimnieciba (Agriculture of Latvia) (2018). Ministry of Agriculture of the Republic of Latvia. Retrieved: https://www.zm.gov.Iv/public/files/CMS_Static_Page_Doc/00/00/01/33/19/Gadazinojums.pdf. Access:04.01.2019.

14. Mikkelsen, B.E., Sylvest, J. (2012). Organic foods on the public plate: technical challenge or organizational change? J. Foodservice Business Res. 15, 64-83.

15. Organic farming statistics (2015). EUROSTAT. Retrieved: http://ec.europa.eu/eurostat/statisticsexplained/index.php/Organic_farming_statistics. Access:04.06.2018.

16. Risku-Norja, H., Loes, A.-K. 2016. Organic food in food policy and in public catering: lessons learned from Finland. Org. Agric. pp. 1-14.

17.Sonnino, R. (2009). Quality food, public procurement, and sustainable development: the school meal revolution in Rome. Environ. Planning A 41, pp. 425-440.

18. Sumberg, J., Sabates-Wheeler, R. (2011). Linking agricultural development to school feeding in SubSaharan Africa: theoretical perspectives. Retrieved: https://www.sciencedirect.com/science/article/abs/pii/S0306919211000406. Access:03.12.2018.

19. Torjusen, H.,Sangstad, L., O'Doherty Jensen, K., Kjærnes, U. (2004). European Consumers' Conceptions of Organic Food: A Review of Available Research (Oslo (SIFO), Norway: National Institute for Consumer's Research). http://orgprints.org/2490/1/ haccprapport.pdf . Accessed 13.09.2017. 